\title{
Faktor-Faktor yang Mempengaruhi Kinerja Reksadana Syariah di Indonesia dan Malaysia
}

\section{Factors Influencing the Performance of Islamic Mutual Funds in Indonesia and Malaysia}

\author{
Rifqi Muhammad $^{1)}$, Imtinani Arifah ${ }^{2)}$, Peni Nugraheni ${ }^{3)}$ \\ ${ }^{1,2)}$ Fakultas Bisnis dan Ekonomi, Universitas Islam Indonesia, Yogyakarta \\ ${ }^{3)}$ Fakultas Ekonomi dan Bisnis, Universitas Muhammadiyah Yogyakarta, Yogyakarta \\ e-mail korespondensi: rifqimuhammad@uii.ac.id
}

\begin{tabular}{|c|c|}
\hline Info Artikel & Abstrak \\
\hline $\begin{array}{l}\text { Riwayat Artikel : } \\
\text { Diterima: } 30 \text { Agustus } 2020 \\
\text { Disetujui: } 22 \text { Januari } 2021 \\
\text { Dipublikasikan: Juli } 2021\end{array}$ & $\begin{array}{l}\text { Penelitian ini bertujuan untuk menguji pengaruh faktor kinerja operasional, umur } \\
\text { reksadana, dan ukuran reksadana, terhadap kinerja reksadana syariah di } \\
\text { Indonesia dan Malaysia. Data yang digunakan berasal dari laporan bulanan } \\
\text { reksadana syariah periode 2016-2018, dan selanjutnya dianalisis menggunakan }\end{array}$ \\
\hline $\begin{array}{l}\text { Nomor DOI } \\
10.33059 / \text { jseb.v12i2.2556 } \\
\text { Cara Mensitasi : } \\
\text { Muhammad, R., Arifah, I., \& } \\
\text { Nugraheni, P. (2021). Faktor- } \\
\text { faktor yang mempengaruhi } \\
\text { kinerja reksadana syariah di } \\
\text { Indonesia dan Malaysia. } \\
\text { Jurnal Samudra Ekonomi dan } \\
\text { Bisnis, 12(2), 154-167. doi: }\end{array}$ & $\begin{array}{l}\text { metode regresi data panel. Total jumlah data sebanyak } 44 \text { buah dari Indonesia } \\
\text { dan } 46 \text { buah dari Malaysia. Hasil pengujian statistik menunjukkan bahwa kinerja } \\
\text { operasional dan ukuran reksadana syariah tidak berpengaruh terhadap kinerja } \\
\text { reksadana syariah baik di Indonesia maupun di Malaysia. Sementara itu, umur } \\
\text { reksadana terbukti berpengaruh negatif signifikan terhadap kinerja reksadana } \\
\text { syariah di Indonesia, namun sebaliknya terdentifikasi memiliki pengaruh positif } \\
\text { signifikan terhadap kinerja reksadana syariah di Malaysia. Lebih jauh, penelitian } \\
\text { ini tidak menemukan adanya perbedaan yang signifikan antara kinerja reksadana } \\
\text { syariah di Indonesia dan Malaysia. }\end{array}$ \\
\hline
\end{tabular}

10.33059/jseb.v12i2.2556.

Kata Kunci: Reksadana Syariah, Kinerja Operasional, Umur, Ukuran.

\begin{tabular}{|l|}
\hline Article Info \\
\hline Article History : \\
Received: 30 August 2020 \\
Accepted: 22 January 2021 \\
Published: July 2021 \\
\hline DOI Number : \\
10.33059/jseb.v12i2.2556 \\
How to cite : \\
Muhammad, R., Arifah, I., \& \\
Nugraheni, P. (2021). Faktor- \\
faktor yang mempengaruhi \\
kinerja reksadana syariah di \\
Indonesia dan Malaysia. \\
Jurnal Samudra Ekonomi dan \\
Bisnis, 12(2), 154-167. doi: \\
10.33059/jseb.v12i2.2556.
\end{tabular}

\begin{abstract}
The study aims to examine the effect of operational performance, age, and size of mutual fund, on the performance of Islamic mutual funds in Indonesia and Malaysia. The data used collected from the monthly reports of Islamic mutual funds for the period 2016-2018, and then analyzed using panel data regression method. The total number of data was 44 from Indonesia and 46 from Malaysia. The results of statistical tests show that the operational performance and size of Islamic mutual funds have no effect on the performance of Islamic mutual funds both in Indonesia and in Malaysia. Meanwhile, the age of mutual funds is proven to have a significant negative effect on the performance of Islamic mutual funds in Indonesia, but on the contrary it is identified as having a significant positive effect on the performance of Islamic mutual funds in Malaysia. Furthermore, this study did not find any significant differences between the performance of Islamic mutual funds in Indonesia and Malaysia.
\end{abstract}

Keywords: Islamic Mutual Fund, Operational Performance, Age, Size. 


\section{PENDAHULUAN}

Pasar modal syariah di Indonesia merupakan suatu wadah bagi kegiatan investasi masyarakat yang menginginkan berinvestasi sesuai dengan prinsip syariah. Sebagai negara dengan penduduk Muslim terbesar di dunia, tersedianya produk investasi yang sesuai syariah di Indonesia tentu menjadi keharusan. Saat ini telah tersedia beberapa produk pada pasar modal syariah Indonesia, diantaranya adalah saham syariah, sukuk dan reksadana syariah.

UU Nomor 8 Tahun 1995 tentang Pasar Modal pada pasal 1 ayat 27 menjelaskan definisi reksadana sebagai wadah yang digunakan dalam upaya menghimpun dana dari masyarakat pemilik modal yang kemudian dana itu diinvestasikan ke dalam Portofolio Efek oleh pihak Manajer Investasi. Sementara itu, definisi reksadana syariah yang terdapat dalam peraturan Otoritas Jasa keuangan (OJK) Nomor 19/POJK.04/2015 tentang Penerbitan dan Persyaratan Reksa Dana Syariah bahwa reksadana yang dimaksud di dalam undang-undang tentang pasar modal tersebut adalah yang memiliki proses pengelolaan tidak bertentangan dengan prinsip syariah.

Kinerja reksadana syariah di Indonesia menunjukkan peningkatan menggembirakan, seperti terlihat dari peningkatan Nilai Aset Bersih (NAB) selama 5 tahun terakhir (tahun 2013-2018). Sejak tahun 2013, NAB reksadana syariah menunjukkan peningkatan yang signifikan hingga tahun 2018 yang mencapai Rp. 34.491, 17 miliar. Demikian juga dengan jumlah reksadana syariah pada setiap tahunnya semakin bertambah, dengan jumlah mencapai 224 reksadana syariah pada tahun 2018. Grafik peningkatan jumlah dan NAB reksadana syariah dapat dilihat pada Gambar 1.

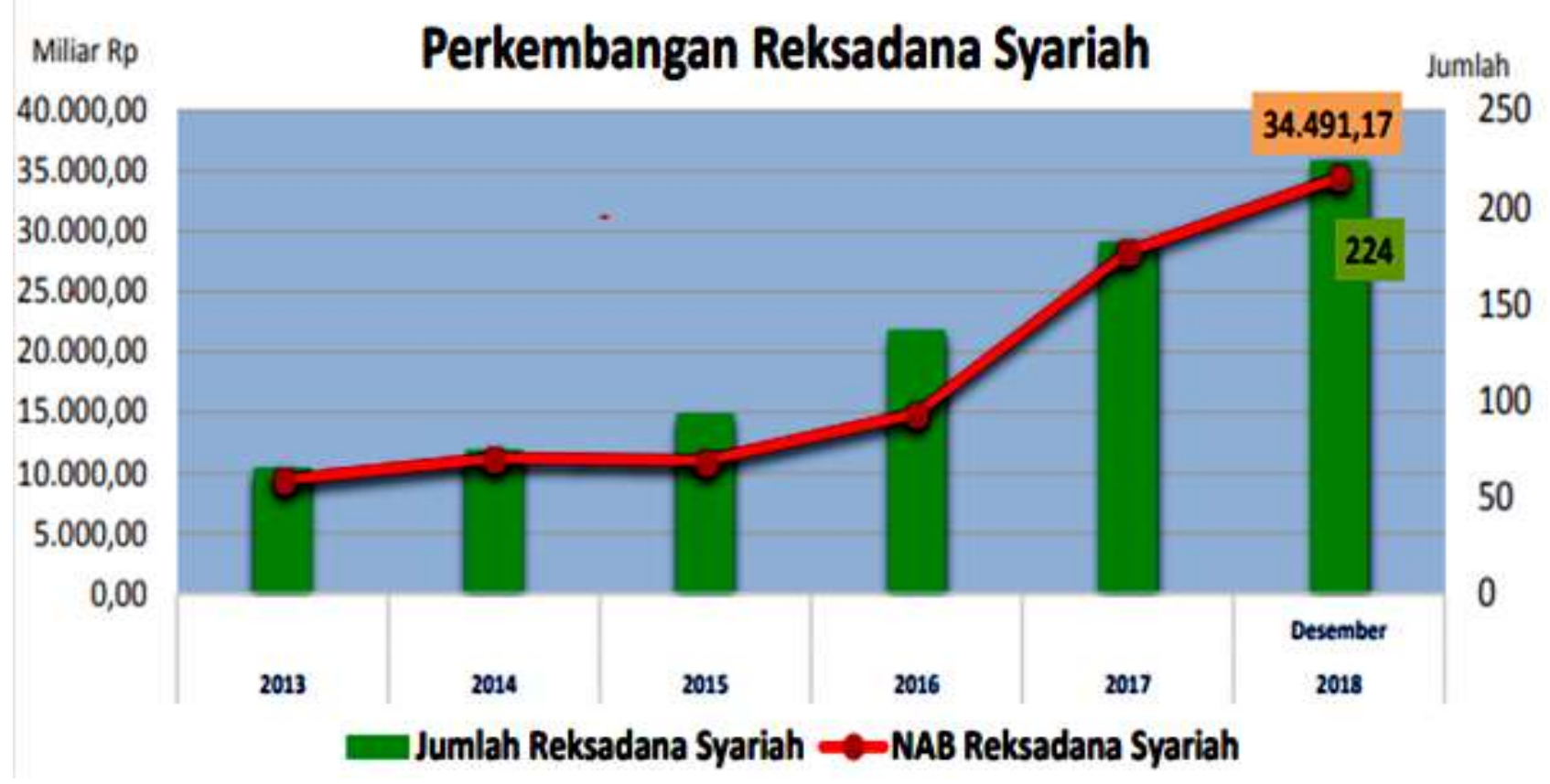

\section{Gambar 1. Perkembangan Reksadana Syariah di Indonesia}

Sumber: www.ojk.go.id, 2018.

Untuk dapat menarik minat investor dalam berinvestasi di reksadana syariah, tentu produk investasi itu harus dapat menunjukkan kinerja yang baik. Beberapa faktor yang mempengaruhi kinerja reksadana maupun kinerja reksadana syariah telah disebutkan pada penelitian sebelumnya seperti kinerja operasional, umur reksadana dan ukuran 
reksadana (See \& Jusoh, 2012; Putri \& Haryanto, 2014; Bitomo \& Muharam, 2016). See \& Jusoh (2012) menemukan bahwa kinerja reksadana dipengaruhi oleh biaya manajemen dan umur, sementara Putri \& Haryanto (2014) menyatakan bahwa kinerja operasional berpengaruh negatif terhadap reksadana. Bitomo \& Muharam (2016) menyatakan bahwa umur dan biaya operasional berpengaruh signifikan terhadap kinerja reksadana, sementara umur reksadana diidentifikasi tidak berpengaruh.

Beberapa penelitian yang menguji pengaruh antara variabel tertentu dengan kinerja reksadana masih berfokus pada reksadana konvensional. Berdasarkan temuan studi Rahmah (2016), kinerja reksadana konvensional lebih baik daripada kinerja reksadana syariah. Oleh karena itu, penelitian ini bertujuan untuk menguji pengaruh faktor kinerja operasional, umur dan ukuran reksadana terhadap kinerja reksadana syariah di Indonesia dan Malaysia. Malaysia dipilih karena selain sama-sama negara dengan mayoritas penduduk Muslim, perkembangan produk investasi syariah di negara tersebut juga berkembang dengan pesat. Malaysia merupakan negara pertama yang mendirikan Islamic Capital Market di ASEAN sejak tahun 1993. Hasil studi Dewi \& Ferdian (2012) menemukan bahwa kinerja reksadana syariah di Malaysia secara umum lebih baik dalam tingkat pertumbuhan dibandingkan dengan negara lain.

\section{Teori Investasi}

Beberapa akademisi telah menjelaskan definisi tentang investasi. Sukirno (1997) menyatakan investasi merupakan pengeluaran atau pembelanjaan dari penanam modal ataupun perusahaan untuk membeli barang modal serta perlengkapan produksi untuk menambah kemampuan melaksanakan proses produksi barang dan jasa yang tersedia dalam aktivitas perekonomian. Sakinah (2014) menyatakam investasi sebagai bentuk penanaman modal atau uamg pada suatu perusahaan ataupun proyek dengan tujuan untuk mendapatkan keuntungan. Berdasarkan beberapa definisi tersebut maka dapat dinyatakan investor melakukan investasi dengan tujuan untuk memperoleh keuntungan baik yang ditujukan untuk jangka pendek maupun jangka panjang. Pemerintah terus berusaha meningkatkan level partisipasi masyarakat melakukan kegiatan investasi, terutama melalui pasar modal Indonesia.

Meski demikian, pertumbuhan investasi di Indonesia pada tahun 2018 sebesar 4,1\% justru jauh lebih kecil daripada tahun 2017 yang mencapai 10\% lebih (Kompas, 2019). Hal ini tentu menjadi perhatian pemerintah karena investasi dapat mempengaruhi tingkat pertumbuhan ekonomi dari suatu negara. Sementara itu, negara Malaysia juga terus memacu pertumbuhan investasi dengan mentargetkan pertumbuhan ekonomi sebesar 4,7\% hingga 4,8\% di tahun 2019 (Anadolu Agency, 2019).

\section{Pandangan Islam mengenai Aktivitas Investasi}

Islam sangat menganjurkan investasi sebagai sarana bagi manusia untuk memproduktifkan harta yang dimiliki, dan tidak hanya sekedar disimpan atau ditimbun. Investasi merupakan salah satu bentuk ikhtiar manusia untuk tidak meninggalkan anak keturunannya dalam keadaan yang lemah (QS. An-Nisa: 9) sekaligus sebagai bentuk aktivitas muamalah dalam rangka membantu sesama manusia melakukan usaha produktif, terutama bagi mereka yang kurang mampu dari sisi modal (Pardiansyah, 2017). Tetapi kegiatan investasi yang dilakukan tersebut tentu saja tidak boleh bertentangan dengan ajaran Islam. 
Islam mendorong manusia memperoleh kebahagiaan dunia maupun akhirat untuk mencapai falah, dan investasi dapat dijadikan salah satu jalan dalam meraih kesejahteraan di dunia. Kegiatan investasi sesuai ajaran Islam tentunya yang tidak bertentangan dengan prinsip syariah. Oleh karena itu, pasar modal syariah dapat dijadikan sarana dalam berinvestasi bagi investor, terutama investor Muslim yang menginginkan aktivitas ekonominya sesuai dengan prinsip Islam (Wiyanti, 2013; Sakinah, 2014).

Instrumen keuangan di pasar modal syariah memberi banyak alternatif investasi bagi pihak investor Muslim seperti saham syariah, sukuk atau obligasi syariah, dan reksadana syariah. Dengan demikian, investor Muslim memiliki banyak alternatif dalam memilih produk investasi yang sesuai dengan tujuan maupun kemampuannya.

\section{Kinerja Reksadana Syariah}

Reksadana syariah juga diatur dalam Fatwa Dewan Syariah Nasional No. 20/DSNMUI/IV/2001 tentang Pedoman Pelaksanaan Investasi untuk Reksadana Syariah. Definisi reksadana syariah menurut fatwa ini adalah "reksadana yang beroperasi menurut ketentuan dan prinsip syariah Islam, baik dalam bentuk akad antara pemodal sebagai pemilik (sahid al-mal / Rabb al Mal) dengan manajer investasi sebagai wakil maupun antara manajer investasi dengan pengguna investasi". Maka segala bentuk investasi yang tidak bertentangan dengan ajaran Islam, termasuk investasi dalam bentuk reksadana syariah, sangat dianjurkan bagi investor Muslim untuk tetap dapat berpartisipasi dalam aktivitas ekonomi.

Ada beberapa jenis reksadana syariah sesuai dengan POJK Nomor 19/POJK04/ 2015 tentang Penerbitan dan Persyaratan Reksadana Syariah, diantaranya adalah reksadana syariah dan reksadana syariah campuran. Reksadana syariah merupakan jenis reksadana yang melakukan investasi paling sedikit $80 \%$ dari Nilai Aktiva Bersih (NAB) ke dalam bentuk efek syariah yang bersifat ekuitas. Sementara reksadana syariah campuran adalah jenis reksadana yang berinvestasi pada efek syariah bersifat ekuitas, efek syariah berpendapatan tetap dan atau instrument pasar uang dalam negeri. Manajer Investasi reksadana bisa menyalurkan paling banyak 79\% dari NAB untuk salah satu dari instrumen investasi tersebut, dimana ketiga instrument tersebut harus ada dalam portofolio reksadana syariah campuran.

Kinerja reksadana diukur dengan Nilai Aktiva Bersih (NAB) dari dana tersebut. Menurut Sudarsono (2003), NAB dapat diperoleh dari jumlah aktiva yang dimiliki seperti kas, deposito, saham, obligasi, Sertifikat Bank Indonesia (SBI), atau Surat Berharga Pasar Uang (SBPU) dan efek lainnya, dikurangi dengan kewajiban seperti insentif untuk manajer investasi, bank kustodian, broker ataupun pajak dan efek yang belum dilunasi.

Goel et al. (2013) menyatakan bahwa kinerja dari setiap reksadana diukur dengan Net Asset Value (NAV). Net Asset Value dipengaruhi oleh faktor-faktor dari skema reksadana yang dikenal sebagai indikator kinerja. Dalam hal ini, kinerja masa lalu reksadana menjelaskan bagaimana dana itu telah dilakukan di masa lalu dan dapat menjadi rujukan apakah produk itu akan berkinerja positif atau negatif di masa depan.

\section{Pengembangan Hipotesis}

Kinerja operasional dapat dilihat dari besarnya biaya operasional reksadana yang dikeluarkan dibandingkan dana kelolaan. Biaya operasional reksadana meliputi biaya manajemen dan biaya administratif. Biaya manajemen merupakan komposisi terbesar dalam pengeluaran biaya operasional, yang 
merupakan pengeluaran untuk pengelolaan portofolio seperti jasa konsultasi dan insentif fund manager, termasuk biaya penelitian dan analisis yang dilakukan. Tujuannya adalah mendapatkan return maksimal dari komposisi portofolio terbaik sehingga dapat menunjang kinerja reksadana. Penelitian yang dilakukan Bitomo \& Muharam (2016) menemukan hubungan positif antara kinerja operasional dan kinerja reksadana. Oleh karena itu, hipotesis penelitian ini adalah:

\section{H1a: Kinerja Operasional berpengaruh positif terhadap Kinerja Reksadana Syariah di Indonesia.}

H1b: Kinerja Operasional berpengaruh positif terhadap Kinerja Reksadana Syariah di Malaysia.

Umur reksadana menunjukkan lamanya waktu suatu reksadana beroperasi, yang dihitung dari tanggal efektif perdagangan reksadana sampai sekarang. Umur reksadana akan mempengaruhi cara pihak manajemen mengelola portofolio dan penempatan arus kas karena telah memiliki pengalaman yang memadai dalam mengelola reksadana. Moore (2016) menyatakan bahwa rekam jejak aatau track record kinerja reksadana dapat dilihat dari lamanya reksadana tersebut beroperasi. Penelitian yang dilakukan oleh Bitomo \& Muharam (2016) menunjukkan bahwa umur reksadana berpengaruh positif pada kinerja reksadana. Berdasarkan argumen tersebut, penelitian ini mengembangkan hipotesis:

H2a: Umur berpengaruh positif terhadap Kinerja Reksadana Syariah di Indonesia.

H2b: Umur berpengaruh positif terhadap Kinerja Reksadana Syariah di Malaysia.

Ukuran reksadana dapat diukur dari jumlah aset yang dimiliki. Besar kecilnya aset akan mempengaruhi kinerja reksadana karena perusahaan bisa menjadi lebih fleksibel dalam penyusunan ataupun pengelolaan portofolio investasi.

Penelitian yang dilakukan oleh Ferreira et al. (2013) tentang kinerja reksadana di 19 negara menunjukkan bahwa ukuran reksadana yang besar akan mendorong kinerja reksadana yang lebih baik. Bitomo \& Muharam (2016) juga menyatakan bahwa ukuran reksadana memiliki pengaruh positif terhadap kinerja reksadana di Indonesia. Oleh karena itu, hipotesis penelitian ini adalah:

H3a: Ukuran berpengaruh positif terhadap Kinerja Reksadana Syariah di Indonesia.

H3b: Ukuran berpengaruh positif terhadap Kinerja Reksadana Syariah di Malaysia.

Indonesia dan Malaysia merupakan negara yang sama-sama mengembangkan pasar modal syariah. Menurut Bloomberg Asia Pacific (Market Bisnis, 2018), industri reksadana di Indonesia diyakini aka nterus berkembang. Investasi di dalam bentuk reksadana menjadi alternatif bagi investor terutama yang tidak memiliki pengetahuan memadai tentang pasar modal. Selain itu, kelebihan reksadana yang lain adalah mudah karena dikelola oleh manajer investasi, harganya yang terjangkau dimana minimum investasi sebesar Rp. 10.000, dan risiko yang lebih kecil karena investasi tersebar pada beberapa efek (OJK, 2019).

Sejak diluncurkan pertama kali tahun 1997, jumlah reksadana syariah terus mengalami peningkatan. Pada tahun 2006 terdapat 17 reksadana syariah dengan NAB Rp. 474 miliar, meningkat menjadi 265 produk reksadana syariah per Agustus 2019 dengan NAB mencapai Rp. 50.290,5 milyar atau sebesar $10 \%$ dari industri (Warninda, 2019). 
Sementara itu, reksadana di Malaysia pada 2018 memiliki kinerja yang buruk karena ekuitas lokal turun akibat ketegangan perdagangan dan kekhawatiran geopolitik global dan lokal. Kepala penelitian Rakuten Trade Sdn Bhd., Kenny Yee (dalam The Malaysian Reserve, 2019), mengatakan kinerja yang lemah di seluruh reksadana pada tahun 2018 sejalan dengan penurunan di pasar keuangan. Dikarenakan sebagian besar dana mengikuti indeks lokal dan/atau global, sehingga dana juga mengikuti ketika pasar bergolak, hanya sedikit yang mengelola untuk memulihkan beberapa kerugian, atau bahkan yang mencatat nilai positif sangat kecil untuk tahun ini.

Beberapa penelitian terdahulu mendapat hasil yang berbeda terkait dengan komparasi kinerja reksadana di Indonesia dan Malaysia. Dewi \& Ferdian (2012) menyatakan bahwa berdasarkan indeks Sharpe, Treynor, Jensen, snail trail methodology dan market timing, studi ini menemukan bahwa reksadana syariah Malaysia tampaknya mengungguli reksadana syariah Indonesia, bahkan dalam periode krisis ekonomi global. Sementara penelitian Basuki \& Khoiruddin (2018) menunjukkan kinerja reksadana syariah di Indonesia lebih unggul dari Malaysia pada tahun 2014 dan 2016, sementara Malaysia mengungguli Indonesia pada tahun 2015. Berdasarkan beberapa pernyataan tersebut, penelitian ini mengembangkan hipotesis:

H4: Kinerja Reksadana Syariah di Indonesia berbeda dengan Kinerja Reksadana Syariah di Malaysia.

\section{METODE PENELITIAN}

Data yang digunakan dalam penelitian ini berupa data sekunder yaitu laporan keuangan yang sudah diterbitkan manajer investasi yang memiliki produk reksadana syariah dan reksadana campuran syariah pada tahun 2018, NAB bulanan, tanggal efektif, dan biaya-biaya. Data tersebut diperoleh dengan cara mengunduh di website sumber data dan masing-masing website dari reksa dana saham.

\section{Penentuan Sampel Penelitian}

Populasi penelitian ini adalah seluruh reksadana syariah dan reksadana syariah campuran di Indonesia dan Malaysia yang tedaftar dan dipublikasikan oleh Otoritas Jasa Keuangan (OJK) dan Securities Commission Malaysia dari tahun 2016-2018. Kedua jenis reksadana ini dipilih karena memiliki karakter risiko yang relatif hampir sama.

Pengambilan sampel menggunakan purposive sampling dengan dua kriteria utama. Kriteria pertama adalah bahwa sampel terpilih merupakan reksadana syariah dan reksadana campuran syariah yang aktif dan terdaftar di Otoritas Jasa Keuangan dan Securities Commission selama periode 20162018 serta telah menerbitkan laporan keuangannya di periode tersebut. Kriteria kedua adalah bahwa sampel terpilih memiliki beberapa kelengkapan data yang dibutuhkan seperti data NAB bulanan periode Desember 2015-Desember 2018, biaya-biaya yang digunakan, total aktiva bersih, dan tanggal efektif reksadana syariah diperdagangkan.

\section{Definisi Operasional Variabel}

\section{Kinerja Operasional}

Kinerja operasional suatu organisasi dapat dilihat dari biaya operasional yang dikeluarkan untuk mendukung kegiatan operasional dari reksadana (Putri \& Haryanto, 2014). Kinerja operasional dihitung dari biaya operasional reksadana dibagi dengan total aset yang dimiliki, dimana nilainya terdapat di laporan keuangan reksadana. Data kinerja operasional diperoleh dari laporan keuangan masing-masing reksadana. Perhitungannya adalah sebagai berikut: 


$$
\text { Kinerja Operasional }=\frac{T B_{t}}{A B_{t}}
$$

dimana $T B_{t}$ adalah total biaya reksadana $i$ pada tahun $t$; dan $A B_{t}$ adalah aktiva bersih reksadana $i$ pada tahun $t$.

\section{Umur}

Umur Reksadana menunjukkan berapa lama reksadana tersebut telah diperdagangkan yang dihitung semenjak tanggal efektif diperdagangkan (Akbarini, 2004). Semakin lama umur reksadana menunjukkan bahwa manajer investasi sudah memiliki pengalaman lebih banyak dalam mengelola portofolio, sehingga kinerjanya juga lebih baik. Manajer yang berpengalaman akan lebih efisien dalam mengelola dan menganalis informasi (Ferreira et al., 2013). Umur reksadana didapatkan dari pengurangan periode penelitian terhadap tanggal efektif reksadana diperdagangkan, lalu diubah dalam bentuk $L n$. Umur reksadana dapat diformulasikan:

Umur $=$ Ln (periode penelitian - tanggal efektif reksadana)

\section{Ukuran}

Ukuran reksadana direpresentasikan dari jumlah aset yang dikelola. Penelitian ini menggunakan Total Net Asset (TNA) untuk mengukur ukuran reksadana (Gruber, 1996). Total Net Asset (TNA) reksadana dihitung dari total aset dikurangi dengan kewajiban yang dimiliki reksadana dan dikonversi ke dalam bentuk $L n$. Formula perhitungan yaitu:

$$
\text { Ukuran }=\text { Ln }(\text { Total Net Asset })
$$

\section{Kinerja Reksadana Syariah}

Kinerja reksadana syariah diukur dari jumlah return yang diberikan kepada investor yang diperoleh atas investasi, yaitu berupa nilai aktiva bersih (NAB). Penelitian ini menggunakan metode Sharpe (1996) untuk mengukur kinerja, dengan rumus:

$$
S R D=\frac{R p-R f}{\sigma p}
$$

dimana $S R D$ adalah nilai Sharpe Ratio; $R p$ adalah rata-rata return reksadana; $R f$ adalah rata-rata return investasi bebas risiko; dan, $\sigma p$ adalah standar deviasi.

\section{Metode Analisis}

Penelitian ini menggunakan data time series dan cross section sehingga analisis menggunakan regresi data panel dengan software Eviews 10. Menurut Widarjono (2009 dalam Basuki dan Yuliadi, 2015:165), regresi data panel memiliki beberapa kelebihan, diantaranya yaitu memiliki degree offreedom yang lebih besar, serta mengurangi masalah ketika terjadi penghilangan variabel (omitted-variable) karena data yang tersedia lebih banyak.

Pemilihan kesesuaian model dalam regresi data panel dapat dilakukan dengan dengan tiga cara, yaitu: (1) menggunakan Uji Chow dengan cara memilih antara common effect models atau fixed effect models; (2) Uji Lagrange-Multiplier (LM) untuk memilih antara commod effect models dengan random effect models; dan, (3) Uji Hausman untuk memilih antara fixed effect models dengan random effect models. Dalam persamaan model regresi data panel bisa dirumuskan dalam model berikut:

$$
\begin{aligned}
Y_{i t}= & \beta_{0}+\beta_{1} X_{1 i t}+\beta_{2} X_{2 i t}+\beta_{3} X_{3 i t}+\beta_{4} X_{4 i t} \\
& +\varepsilon_{i t}
\end{aligned}
$$

Penelitian ini melakukan uji koefisien determinasi $\left(\mathrm{R}^{2}\right)$ untuk mengukur kemampuan model dalam menerangkan variasi variabel independen. Uji $R$-squared memiliki nilai antara 0 sampai dengan 1, karena semakin tinggi nilai yang dimiliki maka hubungan antara variabel independent (bebas) dengan 
variabel dependent (terikat) semakin erat. Kondisi ini menunjukkan variabel independen memiliki kemampuan menjelaskan variabel dependen (Ghozali, 2005).

Uji $F$ memiliki fungsi mengidentifikasi bagaimana pengaruh dari seluruh variabel independent yang ada dalam model ini secara simultan, sementara uji $t$ digunakan untuk mengevaluasi pengaruh dari masing-masing variabel independen atas variabel dependen. Jika tingkat signifikan dari nilai $F$ ataupun $t$ lebih kecil dari nilai alpha sebesar 5\%; maka dinyatakan hipotesis diterima. Penelitian ini juga menggunakan uji Mann-Whitney untuk menilai apakah terdapat perbedaan kinerja reksadana syariah antara di Indonesia dan Malaysia berdasarkan indeks Sharpe.

\section{HASIL ANALISIS}

Tujuan penelitian ini untuk mengetahui dan menganalisis data kinerja operasional, umur, dan ukuran atas kinerja reksadana syariah di Indonesia dan Malaysia pada periode 2016-2018. Berdasarkan kriteria kelengkapan, diperoleh data sebanyak 44 buah untuk reksadana syariah di Indonesia dan 46 buah untuk reksadana syariah di Malaysia.

Hasil analisis awal mengidentifikasi bahwa model dari hasil regresi terbaik untuk Indonesia adalah Random Effect Models (Tabel 1), sementara model dari hasil regresi terbaik untuk Malaysia adalah Fixed Effect Models (Tabel 2).

\section{Tabel 1. Hasil Estimasi Random Effect Indonesia}

\begin{tabular}{lrrrr}
\hline \multicolumn{1}{c}{ Variable } & \multicolumn{1}{c}{ Coefficient } & \multicolumn{1}{c}{ Std. Error } & \multicolumn{1}{c}{ t-Statistic } & \multicolumn{1}{c}{ Prob. } \\
\hline C & 2.053959 & 3.697403 & 0.555514 & 0.5816 \\
KINERJA_OPERASI & 2.583244 & 14.17891 & 0.182189 & 0.8564 \\
UMUR & -1.486043 & 0.459857 & -3.231536 & 0.0025 \\
UKURAN & 0.396633 & 0.210858 & 1.881039 & $0.0673^{*}$ \\
\hline R-squared & 0.241996 & & & \\
Adjusted R-squared & 0.185146 & & & \\
F-statistic & 4.25673 & & & \\
Prob (F-statistic) & 0.010611 & & & \\
\hline
\end{tabular}

Keterangan: *Signifikan pada derajat $\alpha=10 \%$.

Sumber: Data sekunder diolah, 2019.

Tabel 2. Hasil Estimasi Fixed Effect Malaysia

\begin{tabular}{lrrrr}
\hline \multicolumn{1}{c}{ Variable } & \multicolumn{1}{c}{ Coefficient } & \multicolumn{1}{c}{ Std. Error } & \multicolumn{1}{c}{ t-Statistic } & \multicolumn{1}{c}{ Prob. } \\
\hline C & -66.55489 & 15.65445 & -4.251499 & 0.0004 \\
KINERJA_OPERASI & -0.000887 & 0.017409 & -0.050927 & 0.9599 \\
UMUR & 7.697197 & 1.520443 & 5.062469 & 0.0001 \\
UKURAN & -0.058079 & 0.533163 & -0.108932 & 0.9143 \\
\hline R-squared & 0.77479 & & & \\
Adjusted R-squared & 0.493278 & & & \\
F-statistic & 2.752244 & & & \\
Prob (F-statistic) & 0.011995 & & & \\
\hline
\end{tabular}

Sumber: Data sekunder diolah, 2019. 
Tabel 3. Hasil Estimasi Pengujian Hipotesis

\begin{tabular}{lcccc}
\hline \multirow{2}{*}{ Variabel } & \multicolumn{2}{c}{ Indonesia } & \multicolumn{2}{c}{ Malaysia } \\
\cline { 2 - 5 } Kinerja Operasional $\left(\mathrm{X}_{1}\right)$ & Hasil & Pembuktian & Hasil & Pembuktian \\
\hline Jidak & berpengaruh & H1a ditolak & $\begin{array}{c}\text { Tidak } \\
\text { berpengaruh }\end{array}$ & H1b ditolak \\
\hline Umur $\left(\mathrm{X}_{2}\right)$ & $\begin{array}{c}\text { Berpengaruh } \\
\text { negatif }\end{array}$ & H2a ditolak & $\begin{array}{c}\text { Berpengaruh } \\
\text { positif }\end{array}$ & H2b diterima \\
\hline Ukuran $\left(\mathrm{X}_{3}\right)$ & $\begin{array}{c}\text { Berpengaruh } \\
\text { Positif* }\end{array}$ & H3a diterima & $\begin{array}{c}\text { Tidak } \\
\text { berpengaruh }\end{array}$ & H3b ditolak \\
\hline
\end{tabular}

Keterangan: "Signifikan pada derajat $\alpha=10 \%$.

Sumber: Data sekunder diolah, 2019.

Berdasarkan Tabel 1 diperoleh hasil nilai koefisien determinasi atau $\mathrm{R}^{2}$ atas regresi data di Indonesia yaitu 0,241996; yang menunjukkan kinerja reksadana syariah di Indonesia dapat dijelaskan oleh variabelvariabel independen yang dianalisis dalam penelitian ini sebesar $24,20 \%$, dan selebihnya dijelaskan oleh variabel lain. Sedangkan pada Tabel 2 menyatakan hasil nilai koefisien determinasi atau $\mathrm{R}^{2}$ atas regresi data di Malaysia sebesar 0,774790; yang menunjukkan kinerja reksadana syariah di Malaysia bisa dijelaskan variabel-variabel independen yang dianalisis dalam penelitian ini sebesar $24,20 \%$, sementara selebihnya dijelaskan oleh variabel lain.

Nilai F-statistic yang terdapat pada Tabel 1 diperoleh sebesar 4.256730 dengan nilai probabilitas sebesar $0,010611<0,05(\alpha)$; sementara pada Tabel 2 diperoleh nilai probabilitas sebesar 0,011995 < 0,05. Dengan demikian, dapat diidentifikasi bahwa variabelvariabel independen secara bersama-sama dapat mempengaruhi kinerja Reksadana syariah di Indonesia dan Malaysia.

Uji $t$-statistic menjelaskan pengaruh dari variabel-variabel independen secara parsial terhadap variabel dependen, yatu melalui pembandingan nilai probabilitas $t$ dengan nilai $\alpha(5 \%$ dan $10 \%)$ seperti ditunjukkan dalam Tabel 1 dan Tabel 2. Hasil pengujian hipotesis berdasarkan uji $\mathrm{t}$ di Indonesia dan Malaysia dirangkum dalam Tabel 3.

Mula-mula dibahas tentang pembuktian hipotesis untuk reksadana syariah di Indonesia, seperti ditunjukkan dalam Tabel 3. Hasil uji $t$ pada Tabel 1 menunjukkan bahwa kinerja operasional (X1) memiliki nilai koefisien sebesar 0,182189 dengan nilai probabilitas $0,8564>0,05(\alpha=5 \%)$. Artinya secara statistik, kinerja operasional terbukti tidak berpengaruh terhadap kinerja reksadana syariah di Indonesia; sehingga H1a ditolak. Umur (X2) menunjukkan nilai koefisien sebesar $-3,231536$ dengan nilai probabilitas $0,0025<0,05(\alpha=5 \%)$; yang berarti umur reksadana terbukti memiliki pengaruh negatif signifikan terhadap kinerja reksadana syariah di Indonesia, sehingga H2a ditolak. Ukuran (X3) menunjukkan nilai koefisien sebesar 1,881039 dengan nilai probabilitas $0,0673<$ $0,10(\alpha=10 \%)$; yang membuktikan bahwa ukuran reksadana berpengaruh positif dan signifikan terhadap kinerja reksadana syariah di Indonesia, sehingga H3a diterima.

Selanjutnya dibahas tentang pembuktian hipotesis atas reksadana syariah di Malaysia, seperti ditunjukkan dalam Tabel 3. Hasil uji $t$ pada Tabel 1 menunjukkan bahwa kinerja operasional (X1) memiliki nilai koefisien sebesar -0,050927 dengan nilai probabilitas $0,9599>0,05(\alpha=5 \%)$; yang berarti kinerja operasional terbukti tidak mempengaruhi 
kinerja reksadana syariah di Malaysia, sehingga H1b ditolak. Nilai koefisien untuk umur menunjukkan nilai sebesar 5,062469 dengan nilai probabilitas $0,0001<0,05(\alpha=$ $5 \%$ ); yang membuktikan umur reksadana secara signifikan berpengaruh positif terhadap kinerja reksadana syariah di Malaysia, sehingga $\mathrm{H} 2 \mathrm{~b}$ diterima. Ukuran reksadana memiliki nilai koefisien $-0,108932$ dengan nilai probabilitas $0,9143>0,05(\alpha=5 \%)$; yang menyatakan ukuran reksadana terbukti tidak berpengaruh terhadap kinerja reksadana syariah di Malaysia, sehingga H3b ditolak.

\section{Hasil Uji Mann-Whitney}

Uji Mann-Whitney digunakan untuk menguji apakah terdapat perbedaan antara kinerja reksadana syariah di Indonesia dan Malaysia berdasarkan indeks Sharpe. Hasil pengujian ditampilkan dalam Tabel 5.

Berdasarkan output analisis data dalam Tabel 5 diketahui bahwa nilai asymp.Sig (2tailed) sebesar 0,617 >0,05. Hasil tersebut menyatakan bahwa tidak ada perbedaan yang signifikan antara kinerja reksadana syariah di Indonesia dan Malaysia.

Tabel 4. Hasil Uji Mann-Whitney

\begin{tabular}{lllcc}
\hline & \multicolumn{1}{c}{ Negara } & N & Mean Rank & Sum of Ranks \\
\hline \multirow{3}{*}{ Kinerja_Reksadana } & Indonesia & 44 & 46.91 & 2064 \\
& Malaysia & 46 & 44.15 & 2031 \\
& Total & 90 & & \\
\hline
\end{tabular}

\begin{tabular}{lr}
\hline & Kinerja_Reksadana \\
\hline Mann-Whitney & 950 \\
Wilcoxon W & 2031 \\
Z & -0.5 \\
Asymp.Sig.(2-tailed) & 0.617 \\
\hline
\end{tabular}

Sumber: Data sekunder diolah, 2019.

\section{Pembahasan}

\section{Pengaruh Kinerja Operasional terhadap} Kinerja Reksadana Syariah

Hasil pengujian statisistik menunjukkan bahwa kinerja operasional terbukti tidak mempengaruhi kinerja reksadana syariah, baik di Indonesia maupun Malaysia. Hasil penelitian ini menunjukkan bahwa besar kecilnya jumlah biaya yang digunakan pada manajer investasi yang mengeluarkan produk reksadana syariah, tidak dapat mempengaruhi kinerja reksadana syariah. Hasil ini mendukung penelitian Harjono et al. (2017) yang menemukan bahwa kinerja operasional tidak memiliki pengaruh terhadap kinerja reksadana.
Menurut Harjono et al. (2017), strategi pengelolaan dana merupakan hal yang sangat penting bagi seorang manajer investasi. Beberapa macam pengeluaran seperti biaya pemasaran, biaya manajemen, biaya operasi atau biaya administrasi, harus diperhitungkan dengan seksama mengikuti strategi apa yang diterapkan oleh manajer investasi. Oleh sebab itu, kinerja operasional tidak berpengaruh terhadap kinerja reksadana syariah, karena jumlah pengeluaran biaya hanya mengikuti strategi yang diterapkan manajer investasi. Dengan demikian, kinerja reksadana syariah tidak dipengaruhi oleh jumlah biaya yang dikeluarkan, namun dipengaruhi strategi apa yang digunakan oleh manajer investasi. 
Pengaruh Umur Reksadana terhadap Kinerja Reksadana Syariah

Pengujian statistik menunjukkan bahwa umur reksadana syariah berpengaruh negatif dan signifikan terhadap kinerja reksadana syariah. Hal ini berarti semakin lama umur reksadana syariah, maka semakin menurun kinerjanya. Hal ini bisa terjadi ketika manajer investasi gagal menemukan portofolio yang memberikan imbal hasil yang optimal, sementara reksadana yang memiliki umur yang muda memberikan kinerja yang lebih baik agar terus mendapatkan kepercayaan masyarakat terhadap kinerja reksadana. Penelitian ini tidak sejalan dengan studi Moore (2016) yang menemukan bahwa umur tidak mempunyai pengaruh terhadap kinerja reksadana syariah, dimana hal ini berarti walaupun semakin tua umur dari reksadana syariah maka tidak mempengaruhi kinerja reksadana tersebut.

Sebaliknya hasil pengujian hipotesis pada Malaysia menunjukkan bahwa umur reksadana syariah terbukti berpengaruh positif terhadap kinerja reksadana syariah. Hal ini berarti reksadana syariah yang memiliki umur yang lama memiliki kinerja reksadana syariah yang lebih baik. Hasil penelitian ini memperluas temuan penelitian Bitomo \& Muharam (2016) yang menemukan bahwa umur reksadana memiliki pengaruh atas kinerja reksadana.

\section{Pengaruh Ukuran Reksadana terhadap} Kinerja Reksadana Syariah

Pengujian atas hipotesis membuktikan bahwa ukuran reksadana syariah berpengaruh positif dan signifikan terhadap kinerja reksadana syariah di Indonesia, sementara di Malaysia terbukti tidak berpengaruh. Dengan demikian bisa dinyatakan bahwa di Indonesia terdapat kondisi dimana besar kecilnya aset akan mempengaruhi diversifikasi aset sehigga bisa mempengaruhi kinerja reksadana syariah.
Sebaliknya di Malaysia, besar kecilnya aset yang dimiliki reksadana syariah tidak mempengaruhi perubahan kinerja reksadana syariah. Hasil penelitian ini mendukung riset Droms \& Walker (1996) yang menemukan bahwa ukuran reksadana tidak berpengaruh terhadap kinerja reksadana. Hal ini berarti walaupun semakin besar aset yang dimiliki manajer investasi yang mengeluarkan produk reksadana syariah maka dipandang tidak mempengaruhi kinerja reksadana syariah tersebut. Namun penelitian ini tidak sejalan dengan penelitian yang dilakukan oleh Otten \& Bams (2002) yang menemukan bahwa ukuran mempunyai pengaruh terhadap kinerja reksadana.

\section{Perbedaan Kinerja Reksadana Syariah di} Indonesia dan Malaysia

Pengujian yang dilakukan atas hipotesis keempat tidak memperoleh bukti adanya perbedaan kinerja reksadana syariah antara di Indonesia dan Malaysia. Hasil ini berbeda dengan temuan studi Basuki \& Khoiruddin (2018), yang menunjukkan adanya kinerja yang berbeda antara reksadana syariah di Indonesia dengan Malaysia.

Tidak ditemukannya perbedaan kinerja reksadana syariah antara Indonesia dan Malaysia dimungkinkan karena manajer investasi Indonesia dan Malaysia mempunyai preferensi yang sama dalam pemilihan saham untuk menyusun portofolio reksadananya. Penelitian yang pernah dilakukan Covrig (2016) menyatakan bahwa para manajer investasi secara umum memiliki preferensi yang serupa untuk memilih saham yang memberikan kinerja yang bagus.

\section{SIMPULAN}

Penelitian ini bertujuan untuk menguji pengaruh faktor kinerja operasional, umur dan ukuran reksadana terhadap kinerja reksadana syariah di Indonesia dan Malaysia. Hasil 
analisis menunjukkan kinerja operasional dan ukuran reksadana syariah tidak memiliki pengaruh terhadap kinerja reksadana syariah di Indonesia dan Malaysia. Hasil analisis berikutnya menemukan umur reksadana memiliki pengaruh negatif signifikan terhadap kinerja reksadana syariah di Indonesia, sebaliknya umur reksadana disimpulkan berpengaruh positif signifikan atas kinerja reksadana syariah di Malaysia. Penelitian ini juga menemukan tidak ada perbedaan antara kinerja reksadana syariah di Indonesia dan Malaysia.

Penelitian ini memiliki keterbatasan yaitu periode penelitian yang singkat dan variabel yang terbatas. Oleh karena itu, direkomendasikan bagi penelitian selanjutnya untuk menambahkan variabel independen lain yang diduga mempengaruhi kinerja reksadana syariah, seperti market timing ability dan fund cash flow. Selain itu, penelitian berikutnya dapat menambahkan periode penelitian yang lebih lama ataupun menggunakan pengukuran kinerja reksadana dengan metode yang lain, seperti metode Treynor dan metode Jensen.

\section{UCAPAN TERIMA KASIH}

Artikel ini telah dipresentasikan pada Conference on Islamic Management, Accounting and Economics (CIMAE) Volume 2 Tahun 2019 yang diselenggarakan oleh Universitas Islam Indonesia. Penulis mengucapkan terima kasih kepada reviewer CIMAE atas usulan perbaikan pada artikel ini.

\section{REFERENSI}

Akbarini, M. D. (2004). Spesialisasi manajer investasi terhadap kinerja reksadana: Penelitian empiris periode tahun 19992003. Thesis (unpublished). Magister Manajemen Universitas Indonesia, Depok. Retrieved from http://lib.ui. ac.id/file?file=pdf/abstrak-108318.pdf.
Anadolu Agency. (2019). Ekonomi Malaysia diprediksi tumbuh antara 4,7\% hingga 4,8\%. Retrieved from https:// www.aa.com.tr/id/regional/ekonomimalaysia-diprediksi-tumbuh-antara-4-7hingga-4-8-/1432448.

Basuki, A. T. \& Yuliadi, I. (2015). Electronic data processing (SPSS 15 dan Eviews 7). Retrieved from http://repository. umy.ac.id/bitstream/handle/123456789/ 2054/Buku EDP new.pdf?sequence=1\& isAllowed $=\mathrm{y}$.

Basuki, N., \& Khoiruddin, M. (2018). Comparative performance Islamic shares mutual funds between Indonesia and Malaysia. EKUILIBRIUM: Jurnal Bidang Ilmu Ekonomi, 13(1), 26-44. doi : 10.24269/ekuilibrium.v13i1.918.

Bitomo, H., \& Muharam, H. (2016). Analisis faktor-faktor yang mempengaruhi kinerja reksa dana di Indonesia (Studi empiris pada reksa dana konvensional di Indonesia periode 2012-2014). Diponegoro Journal of Management, 5(2), 1-14. Retrieved from https:// ejournal3.undip.ac.id/index.php/djom/a rticle/view/13849.

Covrig, V. (2016). Do domestic and foreign fund managers have similar preferences for stock characteristics? A crosscountry analysis. Journal of International Business Studies, 37(3), 407-429. doi: 10.2139/ssrn.275913.

Dewi, M. K., \& Ferdian, I. R. (2012). Evaluating performance of Islamic mutual funds in Indonesia and Malaysia. Journal of Applied Economics and Business Research, 2(1), 11-33. Retrieved from https:// www.semanticscholar.org/paper/EVAL UATING-PERFORMANCE-OFISLAMIC-MUTUAL-FUNDS-INDewi-Ferdian/003747641e7ad30e511a 114b495244223a95f8b3.

Droms, W. G., \& Walker, D. A. (1996). Mutual fund investment performance. The Quarterly Review of Economics and Finance, 36(3), 347-363. doi: 10.1016/S1062-9769(96)90020-4. 
DSN MUI. (2001). Fatwa Dewan Syariah Nasional No.20/DSN- MUI/IV/2001 tentang pedoman pelaksanaan investasi untuk reksadana syariah. Retrieved from https://dsnmui.or.id.

Ferreira, M. A., Keswani, A., Miguel, A. F., \& Ramos, S. B. (2013). The determinants of mutual fund performance: A cross-country study. Review of Finance, 17(2), 483-525. doi: 10.1093/rof/rfs013.

Ghozali, I. (2005). Aplikasi analisis multivariate dengan SPSS. Badan Penerbit UNDIP.

Goel, S., Mani, M., \& Sharma, R. (2012). A review of performance indicators of mutual funds. Researchers World: Journal of Arts, Science \& Commerce, 3(4), 100-107. Retrieved from https:// www.researchgate.net/publication/3251 15723_A_Review_of_Performance_Ind icators_of_Mutual_Funds.

Gruber, M. J. (1996). Another puzzle: The growth in actively managed mutual funds. Journal of Finance, 51(3), 783810. doi: 10.1111/j.1540-6261.1996. tb02707.x.

Harjono, T. H., Cicilia, E. S., \& Prabowo, F. X. A. J. W. (2017). Biaya operasional reksadana sebagai interverning pengaruh karakteristik reksadana terhadap kinerja reksadana saham di Indonesia. Kajian Ilmiah Mahasiswa Manajemen, 6(2), 72-84. Retrieved from http://journal.wima.ac.id/index. php/KAMMA/article/view/1776.

Kompas. (2019). BKPM: Realisasi investasi tahun 2018 cukup mengecewakan. Retrieved March 5, 2019, from https://ekonomi.kompas.com/read/2019 /02/06/124526126/bkpm-realisasiinvestasi-tahun-2018-cukupmengecewakan.

Market Bisnis. (2018). Bloomberg Asia Pacific: Potensi pertumbuhan reksa dana di Indonesia masih besar. Retrieved from https://market.bisnis. com/read/20180809/92/826263/bloomb erg-asia-pacific-potensi-pertumbuhan - reksa-dana-di-indonesia-masih-besar.

Moore, O. (2016). Mutual fund age, performance, and the optimal track record March 7, 2016. Retrieved from https://pdfs.semanticscholar.org/780b/c 268d44dcb2f9cc1d868aebbe5aebeae40 a0.pdf.

OJK. (1995). Undang-Undang No 8 Tahun 1995 tentang pasar modal. Retrieved from https://www.ojk.go.id.

OJK. (2019). Buku 8 - Industri jasa keuangan syariah, seri literasi keuangan untuk perguruan tinggi. Retrieved from www.ojk.go id.

Otten, R., \& Bams, D. (2002). European mutual fund performance. European Financial Management, 8(1), 75-101. doi: 10.1111/1468-036X.00177.

Pardiansyah, E. (2017). Investasi dalam perspektif ekonomi Islam: Pendekatan teoritis dan empiris. Economica: Jurnal Ekonomi Islam, 8(2), 337-373. doi : 10.21580/economica.2017.8.2.1920.

Putri, C. H. M., \& Haryanto, A. M. (2014). Analisis pengaruh market timing ability, stock selection skill, expense ratio dan tingkat risiko terhadap kinerja reksa dana saham (Studi pada reksa dana saham jenis KIK periode 20092013). Diponegoro Journal of Management, 3(4), 1-10. Retrieved from https://ejournal3.undip.ac.id/ index.php/djom/article/view/12917.

Rahmah, A. (2016). Analisis perbandingan kinerja reksa dana syariah dan kinerja reksa dana konvensional dengan metode Sharpe, Treynor dan Jensen. Analytica Islamica, 5(1), 20-40. Retrieved from http://jurnal.uinsu.ac.id/ index.php/analytica/article/view/478.

Sakinah, S. (2014). Investasi dalam Islam. Iqtishadia: Jurnal Ekonomi dan Perbankan Syariah, 1(2), 248-262. doi: 10.19105/iqtishadia.v1i2.483.

See, Y. P., \& Jusoh, R. (2012). Fund characteristics and fund performance: Evidence of Malaysian mutual funds. International Journal of Economics and Management Sciences, 1(9), 31-43. 
https://www.hilarispublisher.com/abstra $\mathrm{ct} /$ fund-characteristics-and-fundperformanceevidence-of-malaysianmutual-funds-19454.html.

Sharpe, W. F. (1966). Mutual fund performance. The Journal of Business, 39(1), 119-138. doi: 10.1086/294846.

Sudarsono, H. (2003). Bank dan lembaga keuangan syariah: Deskripsi dan ilustrasi. Ekonisia.

Sukirno, S. (1997). Pengantar Teori Mikro Ekonomi $\left(2^{\text {nd }}\right.$ ed.). PT. RajaGrafindo Persada.

The Malaysian Reserve. (2019). Better outcome expected for unit trust funds this year. Retrieved from https:// themalaysianreserve.com/2019/01/18/ better-outcome-expected-for-unit-trustfunds-this-year/.
Warninda. (2019). Perkembangan reksadana syariah di Indonesia tahun 2019. Retrieved from https://www. kompasiana.com.

Wiyanti, D. (2013). Perspektif hukum Islam terhadap pasar modal syariah sebagai alternatif investasi bagi investor. Jurnal Hukum IUS QUIA IUSTUM, 20(2), 234-254. doi: 10.20885/iustum.vol20. iss2.art4. 